\title{
Fe-Ti-V-(P) RESOURCES IN THE UPPER ZONE OF THE BUSHVELD COMPLEX, SOUTH AFRICA
}

\author{
by L.A. Fischer and Q. Yuan
}

(with four text-figures and two plates)

Fischer, L.A. \& Yuan, Q. 2016 (31:viii): Fe-Ti-V-(P) resources in the Upper Zone of the Bushveld Complex, South Africa. Papers and Proceedings of the Royal Society of Tasmania 150(1): 15-22. https://doi.org/10.26749/rstpp.150.1.15 ISSN 0080-4703. Institut für Mineralogie, Leibniz Universität Hannover, 30167 Hannover, Germany, and School of Physical Sciences, University of Tasmania, Hobart, Tasmania 7001, Australia (LAF*); Faculty of Earth Resources, China University of Geosciences, Wuhan 430074, China, and Department of Geology, University of Liege, 4000 Sart Tilman, Belgium (QY). *Author for correspondence. Email: 1.fischer@mineralogie.uni-hannover.de

The Bushveld Complex in South Africa is the largest layered intrusion on Earth. Its upper part is known for huge resources of iron, titanium, vanadium and phosphorus. Associated with the layered character of the rocks, these resources are enriched at certain levels of the intrusion, which makes it important to understand the formation processes of those layers. In this paper we give an introduction and overview of recent debates and challenges.

Key Words: layered intrusion, Bushveld, resources.

\section{INTRODUCTION}

Iron $(\mathrm{Fe})$, titanium $(\mathrm{Ti})$ and vanadium $(\mathrm{V})$ are important resources for the world's economy. While iron is a major material in many industries, titanium and vanadium have become more important during the past decades. Both, titanium and vanadium are important alloying elements in the steel industry, improving the strength and toughness of steel. These steel alloys are in great demand, especially in the aerospace industry.

Continuous industrial development is reflected in the mine production of these elements and their ores or source minerals, which has greatly increased in the past 20 years. The mining of these resources has more than doubled, except for phosphorus $(\mathrm{P})$ production which has increased to a lesser extent (U.S. Geological Survey 2015) (fig. 1). World demand and limited known reserves of those resources emphasise the importance of gaining a better understanding of the processes of formation of their deposits.
Fe, Ti, $\mathrm{V}$ and $\mathrm{P}$ never or only rarely occur as native elements in nature. Minerals, rich in one or more of these elements are mined and their components are extracted. One of the most commonly mined minerals for iron is magnetite $\left(\mathrm{Fe}_{3} \mathrm{O}_{4}\right)$, which can also contain significant concentrations of titanium. The main source for titanium is ilmenite $\left(\mathrm{FeTiO}_{3}\right)$. Both Fe-Ti-oxides can contain economically valuable amounts of vanadium. Phosphorus is extracted from phosphate minerals such as apatite $\left(\mathrm{Ca}_{5}\left(\mathrm{PO}_{4}\right)_{3}(\mathrm{~F}, \mathrm{Cl}, \mathrm{OH})\right)$.

Deposits mined for magnetite, ilmenite and/or apatite can have different origins. Magnetite can be formed by sedimentary, magmatic or biogenic processes. Concentrated magnetite-rich sediment layers are produced by bacteria in marine environments (Devouard et al. 1998), volcanic activity (Nystrom \& Henriquez 1994) or fluvial transport (Fletcher \& Walcott 1991). Ilmenite has a magmatic origin and can be concentrated by fluvial transport (Garzanti et al. 2010). Apatite is commonly formed by magmatic processes (Green \& Watson 1982) or by biomineralisation
FIG. 1 - Annual world production of vanadium and major resource suppliers for iron, titanium and phosphorus. Units are given in the figure. IImenite supplies $90 \%$ of consumed titanium (U.S. Geological Survey 2015). Iron-ore and phosphate rocks are mined for iron and phosphorus, respectively. Annual production data are taken from U.S. Geological Survey (2015).

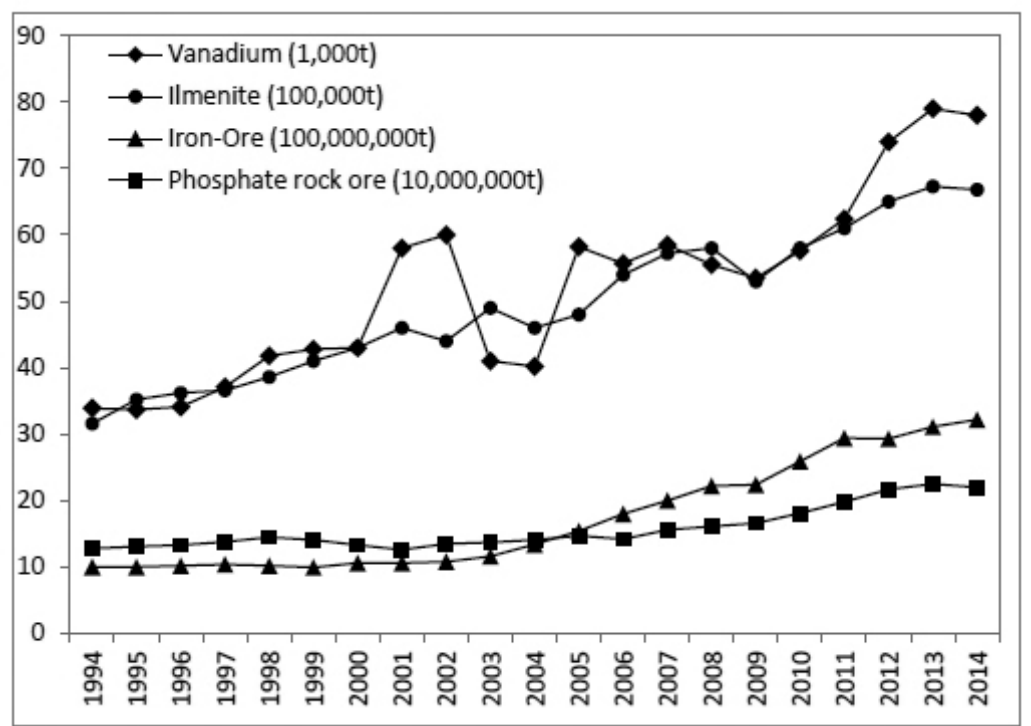


(Hirschler et al. 1990). Importantly, all three minerals are also found in high proportions in certain layers in some solidified magma chambers, called layered intrusions (Eales \& Cawthorn 1996, Song et al. 2013).

\section{LAYERED INTRUSIONS}

Layered intrusions are solidified magma chambers, showing a layering of rocks with different bulk compositions. The differences can be expressed in terms of the variety of minerals present and/or their proportions, and also their textures. The layering is a product of processes occurring during cooling of the magma chamber. Magma is derived from a source within the Earth's mantle to the crust, and causes partial melting of the crust due to the heat excess, as well as updoming and rifting due to buoyancy of the ascending magma. Finally, this process results in an intrusion of magma into the crust. The intruding magma can reach the surface, resulting in a volcanic eruption or can remain in the crust, forming a magma chamber. The level to which the magma ascends depends on buoyancy and viscosity, which is controlled by the magma composition and temperature, as well as crustal structures which provide conduits. The magma composition is determined by the compositions of the initial magma ascending from the mantle, crustal partial melts and potentially due to assimilation of magma chamber wall rocks.

The emplaced magmas have temperatures up to $1250^{\circ} \mathrm{C}$ and are substantially hotter than the crustal host rocks (fig. 2.1). Consequently, the magma cools during and after its intrusion into the crust. Once the temperature is below the liquidus, crystallisation begins. Most crystals sink to the bottom of the magma chamber due to their high density compared to their parental liquid, and form a layer of accumulated minerals (cumulus minerals). With time and progressive cooling more minerals crystallise and settle within the magma chamber, forming horizontal layering until the magma chamber is completely solidified. Since the extraction of crystals from the liquid is accompanied by a change in the liquid's composition, the composition of minerals and thus the rock shows a compositional progression, expressed by the typical layered structure (fig. 2). Rocks formed by crystallisation and settling of minerals are named cumulates.

In nature this process is much more complex. Besides temperature, changes in oxygen fugacity can have dramatic effects on the crystallising phases and thus the path of magmatic evolution (Namur et al. 2015). Also changes in the volatile content $\left(\mathrm{H}_{2} \mathrm{O}\right.$ and $\left.\mathrm{CO}_{2}\right)$ and potential degassing events influence the crystallisation sequence. Moreover, instead of a single crystal composition different minerals can crystallise at the same time, building up a cumulate rock layer. Crystal compositions can change between layers, but also the relative proportions of minerals or their textures can differ. Repeated layers with similar composition are observed in nature. In some cases new magma is injected into an existing magma chamber, affecting the magma compositions and thermodynamic properties of the system which results also in a change of compositions and modes of crystallising minerals. Depending on magma and crystal compositions, crystals can be more buoyant than the magma and therefore float (Campbell 1978, Namur et al. 2011). However, these crystals are commonly found in cumulate layers in certain locations. To explain these occurrences other processes besides crystallisation and settling have to be considered (Namur et al. 2015).
I. Magma chamber

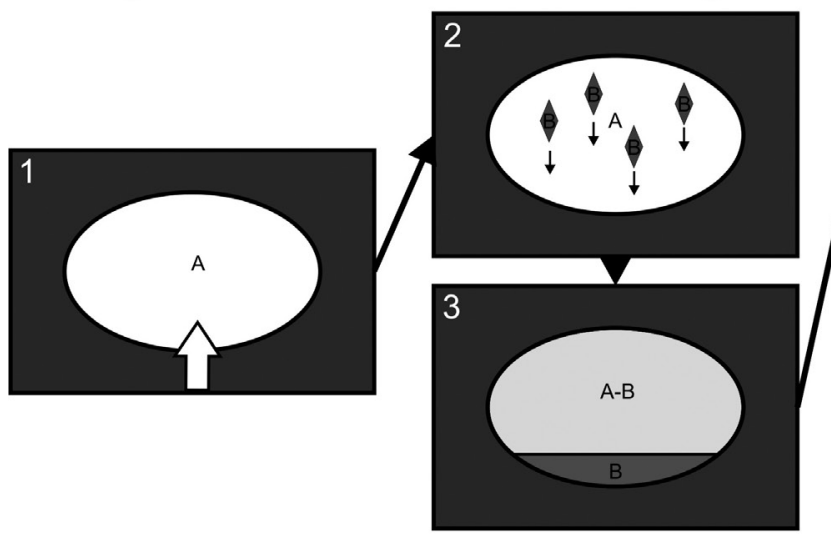

III. Formation of layer C

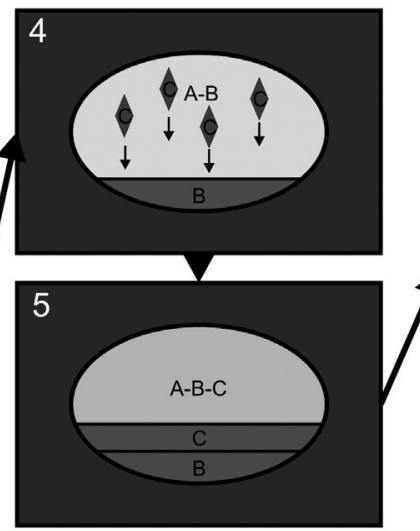

IV. Layered intrusion

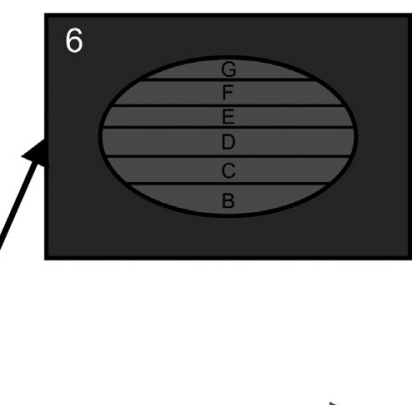

cooling

FIG. 2 - Simplified schematic illustration of the crystallisation and settling process in a layered intrusion. The hot magma, with the composition A intrudes and remains in the crust (fig. 2.1). The magma chamber cools down and crystallisation of crystals with composition B starts (fig. 2.2). Crystals settle at the bottom of the magma chamber and form a layer rich in cumulus minerals having the composition B. The residual magma has the composition A minus B (fig. 2.3). Under different conditions (decreased temperature, different magma composition) crystallising minerals have a different composition $\mathrm{C}$ (fig. 2.4) and the resulting layer is different from the previous one (fig. 2.5). With continuous cooling crystallisation and settling produce more layers with different compositions until the magma chamber is solidified (fig. 2.6). Note that the composition of the residual magma is also strongly dependent on the volume crystallising from the magma but not shown in this simplified figure. 


\section{THE BUSHVELD COMPLEX}

The Bushveld Complex in South Africa (fig. 3) is the largest layered intrusion on Earth. Formed by 1 million $\mathrm{km}^{3}$ of magma (Cawthorn \& Walraven 1998), it covers a $65000 \mathrm{~km}^{2}$ area with a thickness of 7-9 km, emplaced in three limbs (western, eastern and northern limb). Within this giant volume, the world's major resources of platinum and other platinum group elements (PGE), iron, titanium, vanadium, tin and chromium are hosted. The Bushveld Complex is the world's largest resource of PGE. Discovered in the late 1860s by Carl Mauch, it is still one of the most important mining areas in the world. Major resources of PGEs are hosted in the Merensky Reef (MR) and Upper Group 2 Reef (UG2). Both in general 1.5 m-thick layer packages containing chromite $\left((\mathrm{Fe}, \mathrm{Mg}) \mathrm{Cr}_{2} \mathrm{O}_{4}\right)$ dominated layers. Iron and titanium are concentrated in magnetite and ilmenite-rich layers. Prominent examples are the Main Magnetite layer (MM) and the Magnetite layer 21 (M21).

The chemistry of the Bushveld Complex and of its initial magma as well as later injected magmas has been estimated by several authors (e.g., Davies et al. 1980, Van Tongeren et al. 2010, Barnes et al. 2010). Although accurate magma compositions are hotly debated (Cawthorn 2015), the overall mineral assemblage implies a relatively $\mathrm{Mg}$ and/or Fe-rich silicate magma, classified as "mafic". Consequently, the rocks formed from these magmas are mostly mafic rocks. Common mafic minerals for the Bushveld Complex are pyroxene $\left((\mathrm{Mg}, \mathrm{Fe}, \mathrm{Ca})_{2} \mathrm{Si}_{2} \mathrm{O}_{6}\right)$, olivine $\left((\mathrm{Mg}, \mathrm{Fe})_{2} \mathrm{SiO}_{4}\right)$, magnetite and ilmenite.

Zircon $\mathrm{U} / \mathrm{Pb}$ dating has revealed that the initial emplacement of magma in the Bushveld occurred at 2055.91 \pm 0.26 $\mathrm{Ma}$, and the whole intrusion cooled to below $650^{\circ} \mathrm{C}$ (solidified magma chamber) in $1.02 \pm 0.63 \mathrm{Ma}$ (Zeh et al. 2015). Cawthorn \& Walraven (1998) proposed an even shorter crystallisation time of 200000 years.

The Bushveld cumulate rocks are divided into the Marginal, Lower, Critical, Main, Upper and Roof Zones and their corresponding subdivisions (Wager \& Brown 1968, Cawthorn 2013a), based on mineral assemblages (fig. 4). The initial horizontal layering of the Bushveld intrusion was displaced and is now dipping towards the centre of the body (fig. 4). Cawthorn \& Webb (2001) proposed that isostatic adjustment, induced by the huge mass of emplaced magma, is responsible for the tilted layers. Here, we focus on the genetically related Upper and Upper Main Zone (UZa, UZb, UZc and MZu) hereinafter referred as UUMZ.

\section{The Upper and Upper Main Zone}

The UUMZ is commonly considered as representing the last injection of magma into the Bushveld magma chamber and is known as a world-class deposit of Fe, V, Ti and P. The Pyroxenite Marker (PM) is located at the base of the UUMZ (fig. 4), indicating a major change of magma composition between UUMZ and the underlying part of the MZ. It is thought that an injection of new magma changed the

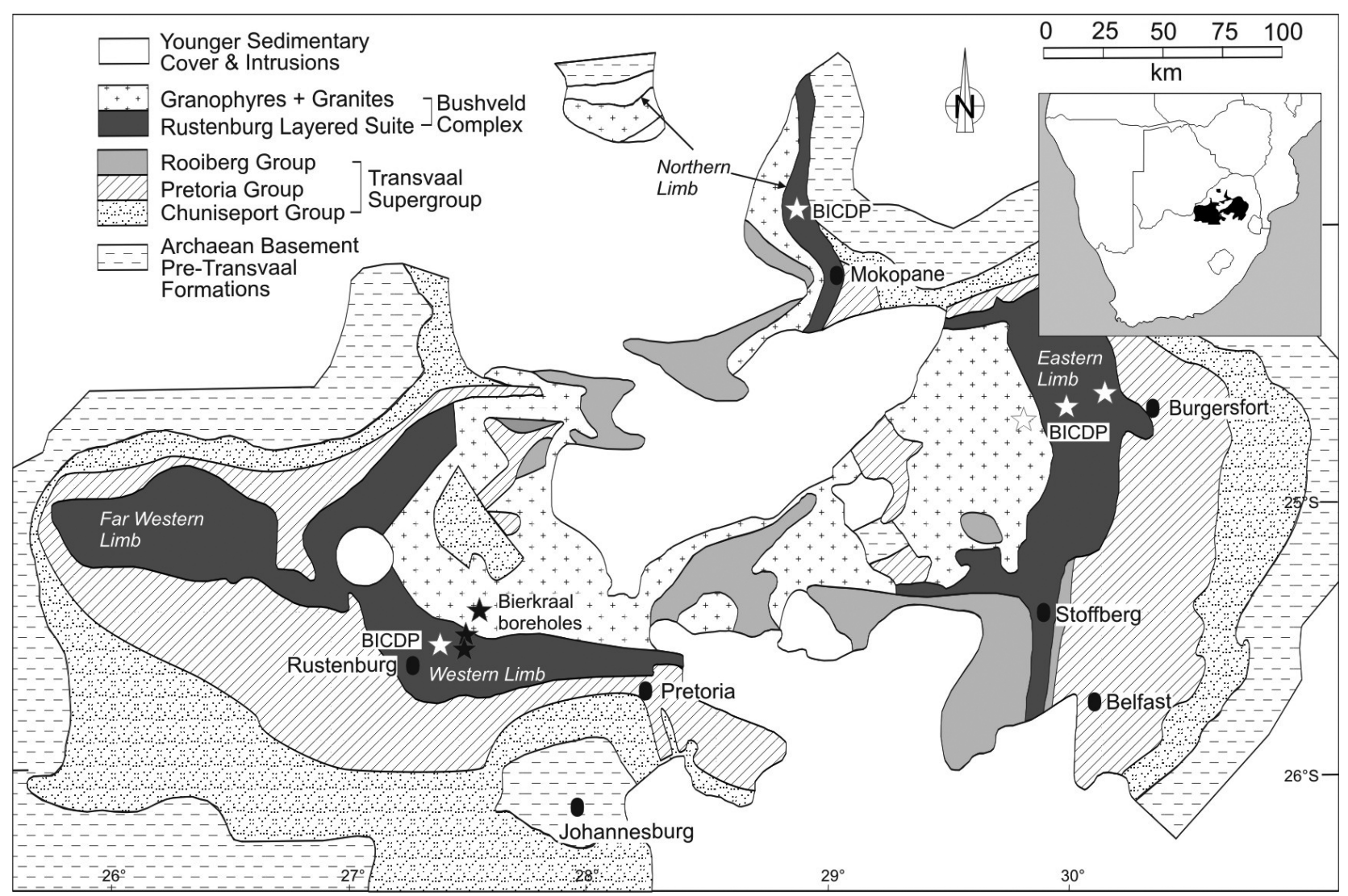

FIG. 3 - Geological map of the Bushveld Complex with location of the Bierkraal boreholes (black stars) and the potential drilling sites of the BICDP (white stars; Trumbull et al. 2015). Modified after Barnes \& Maier (2002). 


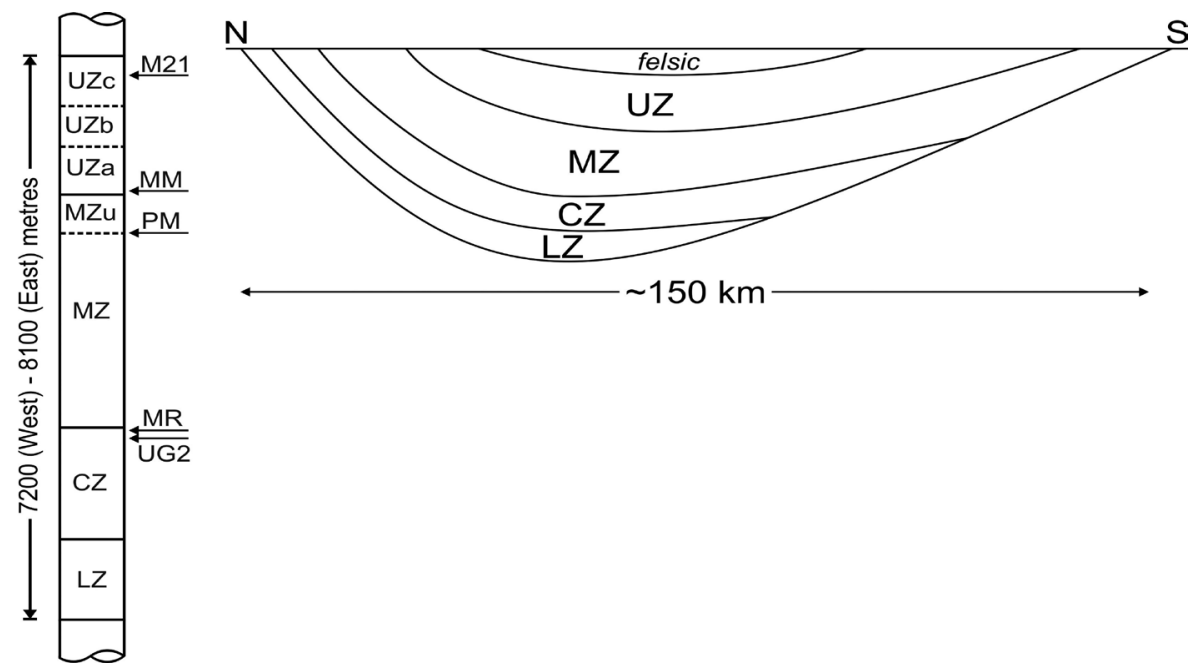

FIG. 4 - Simplified stratigraphic column (left) and cross-section (right) of the western and eastern limb of the Bushveld Complex with Zones and distinctive layers. Lower Zone (LZ), Critical Zone (CZ), Main Zone (MZ) and Upper Zone (UZ) are divided by solid lines. Subdivisions Upper Middle Zone (MZu), Upper Zone a (UZa), Upper Zone b (UZb) and Upper Zone c (UZc) are divided by dashed lines. The distinctive layers the Merensky Reef (MR), Pyroxenite Marker (PM), Main Magnetite layer (MM) and Magnetite layer 21 (M21) are marked with arrows. The thickness of the sequence varies between the eastern and western limbs. Above the UZ, felsic (Si-rich) rocks are located. The LZ is underlain by the Marginal Zone. The north to south cross-section shows the present configuration of the Bushveld layered intrusion. Modified after Eales \& Cawthorn (1996) and Cawthorn \& Webb (2001).

overall magma composition within the Bushveld magma chamber and forced orthopyroxene (Ca-poor pyroxene) to crystallise, resulting in the orthopyroxene-dominated, several metres thick PM (Cawthorn et al. 1991). The UZ can be further subdivided, based on the first appearance (first crystallisation) of new cumulus minerals within the layered sequence. The base of the UZ (subzone $\mathrm{UZa}$ ) is defined by the appearance of cumulus Ti-magnetite (Cawthorn 2015), which is followed by the appearance of olivine (UZb) and finally apatite (UZc).

The UZ stratigraphy is dominated by gabbros with intercalated layers of anorthosite, magnetitite and nelsonite (pl. 1). While anorthosite, a plagioclase-rich rock (plagioclase: mineral series with end-member-formulas $\mathrm{NaAlSi}_{3} \mathrm{O}_{8}-\mathrm{CaAl}_{2} \mathrm{Si}_{2} \mathrm{O}_{8}$ ) is economically unimportant, magnetitite (magnetite and ilmenite) and nelsonite (magnetite, ilmenite and apatite) rocks are enriched in iron, vanadium, titanium and phosphorus. This makes it important to unravel the processes involved in the formation of these layers and the resulting enrichment or depletion of economically valuable elements.

\section{SAMPLING AND PETROGRAPHY}

The exposed part of the Bushveld Complex provides only limited insights into deeper layers. For sampling of unexposed layers, drilling is necessary. The South African Geological Survey drilled three boreholes in the Bierkraal area (BK1, $\mathrm{BK} 2$ and BK3), north of Rustenburg intersecting the UUMZ and the PM (fig. 3). The combined cores provide a 2125-m-thick section of the intrusion. Samples from these drillcores are representative of the UUMZ in the western part of the Bushveld Complex.

The three major rock types identified in the UUMZ are gabbro, anorthosite and $\mathrm{Fe}$-Ti-oxide-rich rocks (magnetitite and nelsonite). Whereas gabbros are a common rock type found in many locations and formed by slowly cooling basaltic magma, the modes of formation of the latter two rock types are still unclear for the UUMZ.

\section{Gabbro}

Gabbro is the dominant rock type in the UUMZ (pl. 2a). It is a typical rock of mafic intrusions and mainly consists of plagioclase, pyroxene and/or olivine. Distinctive for the UUMZ gabbros are their high proportions of plagioclase, magnetite and apatite. The latter mineral shows a cyclic vertical variation in abundance (Tegner et al. 2006). Gabbros vary markedly throughout all subdivisions in terms of mineral modes and compositions as well as textures.

\section{Anorthosite}

Minor proportions of anorthosite occur as repetitive layers within the UUMZ (pl. 2b). Compared to other rock types found in the UUMZ, they are classified as felsic rocks (rich in $\mathrm{Si}-\mathrm{Al})$. The main mineral is plagioclase with smaller proportions of mafic minerals (pyroxene and magnetite). Most anorthosite samples show slight local alteration, expressed in minerals formed after the cooling of the magma chamber (e.g., epidote, amphibole).

\section{Magnetitite and nelsonite}

Tegner et al. (2006) identified 26 magnetite layers and six nelsonite layers in the Bierkraal drillcores of the UUMZ, with a total thickness of $20.42 \mathrm{~m}$. Magnetitite consists of massive magnetite, ilmenite and plagioclase with a few pyroxenes (pl. 2c). Magnetites from the UUMZ show a relatively high $\mathrm{Ti}$ concentration, ranging from 5 to $20 \mathrm{wt} \%$ $\mathrm{TiO}_{2}$ (Reynolds 1985). 


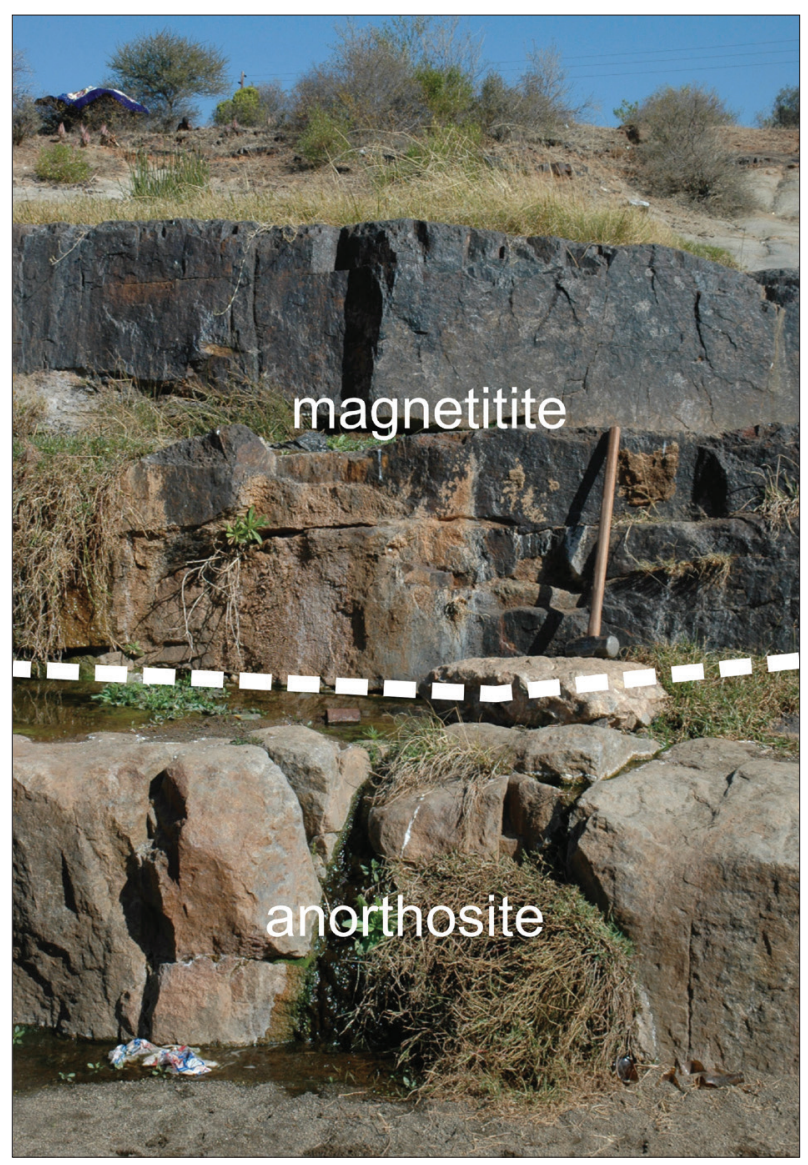

PLATE 1 - Photograph of the dark Main Magnetite layer overlaying a bright anorthosite layer in the Upper Zone. Photograph from Scoon \& Mitchell (2012), reproduced with permission.

Nelsonites contain, in addition to the magnetitite assemblage, significant amounts of apatite.

\section{SCIENTIFIC DEBATES AND CONTROVERSIES}

Although the Bushveld Complex has been studied for more than 150 years, several recent debates and controversies emphasise the uncertainties in the understanding of this layered intrusion.

\section{Closed- or open-system}

Closed-system crystallisation means that the magma evolves and cools progressively in the magma chamber without magma eruptions or any new input of new magma, usually referred to as magma replenishment. Whether the UUMZ in the Bushveld formed in a closed system has been debated in recent years. Based on the generally consistent initial strontium isotope ratios $(0.7073 \pm 0.0002)$ of the host rocks, some researchers have concluded that the UUMZ formed by differentiation of a single magma body (Kruger et al. 1987, Cawthorn et al. 1991, Van Tongeren et al. 2010, Tegner et al. 2006). By contrast, due to an observed significant loss of incompatible elements such as $\mathrm{K}$ and $\mathrm{Zr}$, Cawthorn \& Walraven (1998) proposed that up to $40 \%$ of the magma may have been erupted. In addition, the documented compositional reversals and the obvious isotopic differences between cumulus minerals strongly indicate that the UUMZ experienced a succession of magma pulses (Ashwal et al. 2005, Scoon \& Mitchell 2012, Tanner et al. 2014).

\section{Mush emplacement versus magma recharge}

The difference between the emplacement of a crystal mush and a crystal-free silicate liquid is due to the crystal load transported by the magma. In contrast to the generally assumed crystal-free liquid in many models of magma evolution (Marsh 2004, Latypov 2009), recent studies suggest that most injected magma can carry crystals, with concentration of up to $55 \mathrm{vol} \%$ (Marsh 2013). In addition, emplacement of plagioclase-rich mush has been proposed for the thick anorthosite layers in another layered intrusion (Stillwater Complex, Montana) (Raedeke 1982) and is also regarded as a widely accepted process to form the Proterozoic massif-type anorthosites (Ashwal 1993). Based on the magnetic susceptibility and non-cotectic proportions of plagioclase, Ashwal et al. (2005) and Roelofse \& Ashwal (2012) suggest that this mechanism may have occurred in the UUMZ and lower Main Zone, implying the existence of a sub-Bushveld magma chamber, progressively feeding the actual Bushveld chamber with evolved magma.

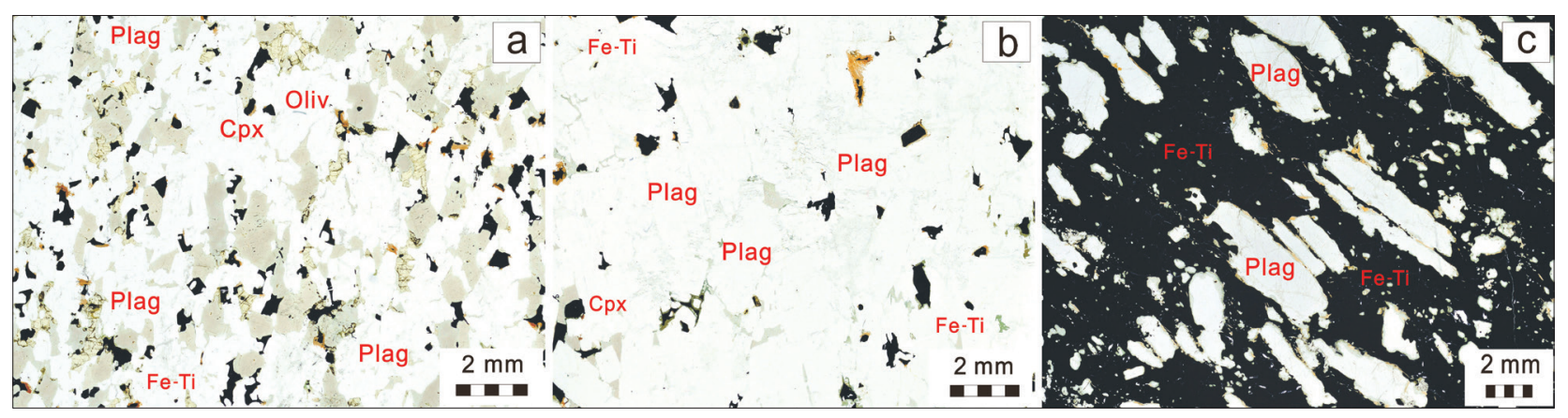

PLATE 2 - Thin section photographs of selected representative rocks from the Upper Zone. a: Gabbro, b: Anorthosite; c: Magnetitite. Plag, plagioclase; Cpx, clinopyroxene; Oliv, olivine; Fe-Ti, Fe-Ti oxides. 


\section{Liquid immiscibility}

Silicate liquid immiscibility is the unmixing of two or more silicate liquids (magmas) with different compositions from a single parental magma. The unmixing of an iron-rich silicate liquid and a silica-rich silicate liquid has been identified in several locations with genetic similarities to the Bushveld Complex (e.g., Skaergaard intrusion in Greenland (Jakobsen et al. 2005) and Sept Iles intrusion in Canada (Namur et al. 2012)). In the case of the Bushveld Complex, the development of immiscible silicate liquids within the magma body has been debated and controversially interpreted. Cawthorn (2013b) challenged the occurrence of silicate liquid immiscibility, whereas von Gruenewaldt (1993) suggested that silicate liquid immiscibility might have produced the up to m-scale magnetitite and nelsonite layers. Alternatively, Van Tongeren \& Mathez (2012) argue that even large-scale separation of iron- and silica-rich melts at the hundreds-of-metre scale might have occurred. The latter model has been widely debated (Cawthorn 2014, VanTongeren \& Mathez 2014) but consensus has not yet been reached, mainly because of the absence of any direct evidence for the existence of immiscible melts. Recently, Fischer et al. (2016) proposed that silicate liquid immiscibility occurred on a smaller scale $(50-200 \mathrm{~m})$ in the UMMZ. They suggest that sorting of immiscible melt droplets in the crystal mush possibly resulted in forming iron-rich layers within the UZ.

\section{Link between limbs}

The Bushveld Complex is exposed in three limbs, namely the western, eastern and northern limbs. Gravity models and seismic tomography have shown that the eastern and western limbs are connected at depth (Webb et al. 2004, Kgaswane et al. 2012). This is also supported by the finding of similar layers and sequences in the two limbs. Cawthorn \& Webb (2001) identified six equivalent layers in the eastern and western limbs and concluded that both limbs crystallised from a single magma chamber. The presently exposed structure with two limbs is the result of isostatic depression (Cawthorn \& Webb 2001).

Connection between the northern limb and the western and eastern limbs is also debated. Possibly equivalent layers were identified but no conclusive evidence could be provided (Kinnaird et al. 2005). Cawthorn (2015) suggested discrete evolution of the northern limb at least for the Lower and Critical Zones, based on the lack of equivalent chromitite layers in the western and eastern limbs. Ashwal et al. (2005) found possibly correlating layers of the Main and Upper Zone within the northern limb.

\section{CURRENT WORK}

\section{Systematic rock and mineral chemistry study}

Until now, there have been no systematic studies of wholerock compositions in the western limb, which is an important part of the Bushveld Complex. Therefore, to better constrain the magma chamber processes associated with the UUMZ, we have collected 262 samples from the Bierkraal drillcores in the western limb of the Bushveld Complex and determined whole-rock compositions together with constituent mineral compositions and performed mineral modal proportion analysis for most samples. This extensive database will allow us to obtain precise information on the mineral modes and their variations throughout the $2-\mathrm{km}$-thick stratigraphy. In addition, the new data, together with the published $\mathrm{V}_{2} \mathrm{O}_{5}$ contents in magnetites for the same drillcores (Cawthorn \& Walsh 1988), clearly indicate that the UUMZ does not correspond to a single closed system but instead exhibits several consistent compositional reversals suggesting events of magma chamber replenishment.

\section{Melt inclusion study}

During crystallisation in the magma chamber crystals can trap small amounts of the liquid from which they grow. These tiny pockets of liquid are preserved as glass and/or minerals within host crystals, while the magma evolves further. By analysing those melt inclusions we can gain information on the magma composition. These data help us to identify processes and conditions controlling the formation of the rocks and the composition of the magma prior to crystallisation.

In the UZ of the Bushveld Complex various types of inclusions can be observed in apatite. Composed of polycrystalline assemblages, such inclusions are commonly interpreted to represent crystallised equilibrium melt, trapped during the growth of apatite. They thus have the potential to record the composition of stable melts.

Recent results for Bushveld melt inclusions are presented and discussed in Fischer et al. (2016). They analysed 99 melt inclusions hosted in apatite of the UUMZ. Prior to analysis they re-homogenised the polycrystalline inclusions at $1100^{\circ} \mathrm{C}$ and a pressure of $100 \mathrm{MPa}$. Major element analyses showed a range of compositions from iron- to silica-rich. They interpret this as a result of silicate liquid immiscibility, possibly involved in forming iron-rich layers within the UZ.

\section{Experimental study}

We plan to experimentally simulate magma chamber processes to reconstruct the magmatic evolution of the UUMZ. We will use Internally Heated Pressure Vessels (IHPV, details described in Berndt et al. (2002)) to perform high-pressure, high-temperature experiments. Therefore, we use a synthetic magma composition contained within Ptgraphite or Au-Pd capsules, which crystallises in the course of the experiments to a mineral assemblage controlled by the applied experimental conditions. Experimental pressures and temperatures will vary within a range plausible for crustal intrusions. Run durations will range between 3-7 days to maintain equilibrium conditions between crystals and melt. Experimentally produced phases (residual magma and crystals) can be later analysed, providing important insights into phase stabilities as a function of thermodynamic conditions. 
The general aim of these experiments is to match melt inclusion and residual magma compositions as well as natural and experimentally obtained crystals. This enables us to define the formation conditions (temperature, pressure, oxygen fugacity) for distinct layers, to test if silicate liquid immiscibility could have occurred during magmatic evolution, and to determine the conditions of the possible onset of the liquid unmixing process.

\section{Bushveld Igneous Complex Drilling Project}

The Bushveld Igneous Complex Drilling Project (BICDP) (Trumbull et al. 2015) is part of the work of the International Continental Drilling Program (ICDP), an international organisation supporting scientific continental drilling projects. Directed by two research groups from Germany (GFZ-German Research Centre for Geosciences) and South Africa (University of the Witwatersrand, Johannesburg) the BICDP started in 2014 and is currently in the planning stage. It comprises three different drill sites, one site at each limb of the intrusion (fig. 3). Combined with existing drillcores those obtained from the BICDP will cover the complete Bushveld stratigraphy in each limb. In addition to other benefits, this allows researchers to investigate vertical and lateral variations and may resolve the controversy concerning the relationships between the different limbs.

\section{SUMMARY}

The Bushveld Complex contains major resources of PGEs, iron, titanium, vanadium and other elements. With increasing demand for these elements, the Bushveld deposits are of critical economic interest. The distribution of valuable elements follows the characteristics of a layered intrusion in that certain elements are concentrated at distinct levels of the intrusion. However, the actual processes involved in the formation of these layers are still controversially debated. We have produced a systematic dataset for whole rock, mineral and melt inclusion compositions for the upper part of the Bushveld Complex and will complement these data with an experimental study of magma crystallisation. This will allow us to approach recent questions with new arguments.

\section{ACKNOWLEDGEMENTS}

This project was supported by a DAAD-Doktorandenstipendium for L.A. Fischer. O. Namur, B. Charlier, F. Holtz and A. Husen are thanked for discussions and their comments. The comments of two anonymous reviewers improved the quality of this paper.

\section{REFERENCES}

Ashwal, L. 1993: Anorthosites Springer, Heidelberg: 422 pp. Ashwal, L.D., Webb, S.J. \& Knoper, M.W. 2005: Magmatic stratigraphy in the Bushveld Northern Lobe: Continuous geophysical and mineralogical data from the $2950 \mathrm{~m}$
Bellevue drillcore. South African Journal of Geology 108 : 199-232.

Barnes, S-J. \& Maier, W.D. 2002: Platinum-group element distributions in the Rustenberg Layered Suite of the Bushveld Complex, South Africa. In Cabri L.J. (ed): The Geology, Geochemistry, Mineralogy and Mineral Beneficiation of Platinum-Group Elements. Canadian Institute of Mining, Metallurgy and Petroleum, Special Volume 54: 431-458.

Barnes, S-J., Maier, W.D. \& Curl, E.A. 2010: Composition of the Marginal Rocks and Sills of the Rustenburg Layered Suite, Bushveld Complex, South Africa: Implications for the Formation of the Platinum-Group Element Deposits. Economic Geology 105: 1491-1511.

Berndt, J., Liebske, C., Holtz, F., Freise, M., Nowak, M., Ziegenbein, D., Hurkuck, W. \& Koepke, J. 2002: A combined rapid-quench and $\mathrm{H}_{2}$-membrane setup for internally heated pressure vessels: Description and application for water solubility in basaltic melts. American Mineralogist 87: 1717-1726.

Campbell, I.H. 1978: Some problems with the cumulus theory. Lithos 11: 311-323.

Cawthorn, R.G. \& Walraven, F. 1998: Emplacement and Crystallization Time for the Bushveld Complex. Journal of Petrology 39: 1669-1687.

Cawthorn, R.G. \& Walsh, K.L. 1988: The use of phosphorus contents in yielding estimates of the proportion of trapped liquid in cumulates of the Upper Zone of the Bushveld Complex. Mineralogical Magazine 52: 81-89.

Cawthorn, R.G. \& Webb, S.J. 2001: Connectivity between the western and eastern limbs of the Bushveld complex. Tectonophysics 330: 195-209.

Cawthorn, R.G. 2013a: The Residual or Roof Zone of the Bushveld Complex, South Africa. Journal of Petrology 54: 1875-1900.

Cawthorn, R.G. 2013b: Rare earth element abundances in apatite in the Bushveld Complex - A consequence of the trapped liquid shift effect. Geology 41: 603-606.

Cawthorn, R.G. 2014: Rare earth element abundances in apatite in the Bushveld Complex - A consequence of the trapped liquid shift effect: REPLY. Geology 42: e319-e319.

Cawthorn, R.G. 2015: The Bushveld Complex, South Africa. In Charlier, B., Namur, O., Latypov, R. \& Tegner, C. (eds): Layered Intrusions. Springer, Netherlands: 517-587.

Cawthorn, R.G., Meyer, P.S. \& Kruger, F.J. 1991: Major addition of magma at the pyroxenite marker in the western bushveld complex, South Africa. Journal of Petrology 32: 739-763.

Davies, G., Cawthorn, R.G., Barton, J.M. \& Morton, M. 1980: Parental magma to the Bushveld complex. Nature 287: 33-35.

Devouard, B., Pósfai,M., Hua, X., Bazylinski, D.A., Frankel, R.B. \& Buseck, P.R. 1998: Magnetite from magnetotactic bacteria: Size distributions and twinning. American Mineralogist 83: 1387-1398.

Eales, H.V. \& Cawthorn, R.G. 1996: The Bushveld Complex. In Cawthorn, R.G. (ed): Layered Intrusions. Elsevier, Amsterdam: 181-229.

Fischer, L.A., Wang, M., Charlier, B., Namur, O., Roberts, R.J., Veksler, I. V., Cawthorn, R.G. \& Holtz, F. 2016: Immiscible iron-and silica-rich liquids in the Upper Zone of the Bushveld Complex. Earth and Planetary Science Letters 443: 108-117.

Fletcher, W.K. \& Wolcott, J. 1991: Transport of magnetite and gold in Harris Creek, British Columbia, and implications for exploration. Journal of Geochemical Exploration 41: 253-274.

Garzanti, E., Andò, S., France-Lanord, C., Vezzoli, G., Censi, P., Galy, V. \& Najman, Y. 2010: Mineralogical and chemical variability of fluvial sediments 1 . Bedload sand (Ganga-Brahmaputra, Bangladesh). Earth and Planetary Science Letters 299: 368-381. 
Green, T.H. \& Watson, E.B. 1982: Crystallization of apatite in natural magmas under high pressure, hydrous conditions, with particular reference to "Orogenic" rock series. Contributions to Mineralogy and Petrology 79: 96-105.

Hirschler, A., Lucas, J. \& Hubert, J-C. 1990: Bacterial involvement in apatite genesis. FEMS Microbiology Ecology 73: 211-220.

Jakobsen, J.K., Veksler, I.V., Tegner, C. \& Brooks, C.K. 2005 Immiscible iron- and silica-rich melts in basalt petrogenesis documented in the Skaergaard intrusion. Geology 33: 885.

Kgaswane, E.M., Nyblade, A.A., Durrheim, R.J., Julià, J., Dirks, P.H.G.M. \& Webb, S.J. 2012: Shear wave velocity structure of the Bushveld Complex, South Africa. Tectonophysics 554-557: 83-104.

Kinnaird, J.A., Hutchinson, D., Schurmann, L., Nex, P.A.M. \& de Lange, R. 2005: Petrology and mineralisation of the southern Platreef: Northern limb of the Bushveld Complex, South Africa. Mineralium Deposita 40: 576-597.

Kruger, F.J., Cawthorn, R.G. \& Walsh, K.L. 1987: Strontium isotopic evidence against magma addition in the Upper Zone of the Bushveld Complex. Earth and Planetary Science Letters 84: 51-58.

Latypov, R. 2009: Testing the validity of the petrological hypothesis "no phenocrysts, no post-emplacement differentiation". Journal of Petrology 50: 1047-1069.

Marsh, B. 2004: A magmatic mush column rosetta stone: The McMurdo Dry Valleys of Antarctica. Eos, Transactions American Geophysical Union 85: 497.

Marsh, B.D. 2013: On some fundamentals of igneous petrology. Contributions to Mineralogy and Petrology 166: 665-690.

Namur, O., Abily, B., Boudreau, A.E., Blanchette, F., Bush, J.W.M., Ceuleneer, G., Charlier, B., Donaldson, C.H., Duchesne, J-C., Higgin, M.D., Morata, D., Nielsen, T.F.D., O'Driscoll, B., Pang, K.N., Peacock, T., Spandler, C.J., Toramaru, A. \& Veksler, I.V. 2015: Igneous Layering in Basaltic Magma Chambers. In Charlier, B., Namur, O., Latypov, R. \& Tegner, C. (eds): Layered Intrusions. Springer, Netherlands: $75-152$

Namur, O., Charlier, B. \& Holness, M.B. 2012: Dual origin of Fe-Ti-P gabbros by immiscibility and fractional crystallization of evolved tholeiitic basalts in the Sept Iles layered intrusion. Lithos 154: 100-114.

Namur, O., Charlier, B., Pirard, C., Hermann, J., Liégeois, J-P. \& Vander Auwera, J. 2011: Anorthosite formation by plagioclase flotation in ferrobasalt and implications for the lunar crust. Geochimica et Cosmochimica Acta 75: 4998-5018.

Nystrom, J.O. \& Henriquez, F. 1994: Magmatic features of iron ores of the Kiruna type in Chile and Sweden: ore textures and magnetite geochemistry. Economic Geology 89: 820-839.

Raedeke, L.D. 1982: Petrogenesis of the Stillwater Complex Unpublished $\mathrm{PhD}$ thesis, University of Washington.

Reynolds, I.M. 1985: Contrasted mineralogy and textural relationships in the uppermost titaniferous magnetite layers of the Bushveld complex in the Bierkraal area north of Rustenburg. Economic Geology 80: 1027-1048.
Roelofse, F. \& Ashwal, L.D. 2012: The Lower Main Zone in the Northern Limb of the Bushveld Complex - a $>1.3 \mathrm{~km}$ Thick Sequence of Intruded and Variably Contaminated Crystal Mushes. Journal of Petrology 53: 1449-1476.

Scoon, R.N. \& Mitchell, A.A. 2012: The upper zone of the bushveld complex at Roossenekal, South Africa: Geochemical stratigraphy and evidence of multiple episodes of magma replenishment. South African Journal of Geology 115: 515-534.

Song, X-Y., Qi, H-W., Hu, R-Z., Chen, L-M., Yu, S-Y. \& Zhang, J-F. 2013: Formation of thick stratiform Fe-Ti oxide layers in layered intrusion and frequent replenishment of fractionated mafic magma: Evidence from the Panzhihua intrusion, SW China. Geochemistry, Geophysics, Geosystems 14: $712-732$

Tanner, D., Mavrogenes, J.A., Arculus, R.J. \& Jenner, F.E. 2014: Trace Element Stratigraphy of the Bellevue Core, Northern Bushveld: Multiple Magma Injections Obscured by Diffusive Processes. Journal of Petrology 55: 859-882.

Tegner, C., Cawthorn, R.G. \& Kruger, F.J. 2006: Cyclicity in the Main and Upper Zones of the Bushveld Complex, South Africa: Crystallization from a Zoned Magma Sheet. Journal of Petrology 47: 2257-2279.

Trumbull, R.B., Ashwal, L.D., Webb, S.J. \& Veksler, I.V. 2015: Drilling through the largest magma chamber on Earth: Bushveld Igneous Complex Drilling Project (BICDP). Scientific Drilling 19: 33-37.

U.S. Geological Survey 2015: Mineral Commodity Summaries U.S. Geological Survey.

VanTongeren, J.A. \& Mathez, E.A. 2012: Large-scale liquid immiscibility at the top of the Bushveld Complex, South Africa. Geology 40: 491-494.

VanTongeren, J.A. \& Mathez, E.A. 2014: Rare earth element abundances in apatite in the Bushveld Complex-A consequence of the trapped liquid shift effect: Comment. Geology 42: e318.

VanTongeren, J.A., Mathez, E.A. \& Kelemen, P.B. 2010: A felsic end to Bushveld differentiation. Journal of Petrology 51: 1891-1912.

von Gruenewaldt, G. 1993: Ilmenite-apatite enrichments in the upper zone of the Bushveld complex: a major titaniumrock phosphate resource. International Geology Review 35: 987-1000.

Wager, L.R. \& Brown, G.M. 1968: Layered Igneous Rocks. Oliver and Boyd, London: 588 pp.

Webb, S.J., Cawthorn, R.G., Nguuri, T. \& James, D. 2004: Gravity modeling Bushveld complex connectivity supported by Southern African Seismic Experiment results. South African Journal of Geology 107: 207-218.

Zeh, A., Ovtcharova, M., Wilson, A.H. \& Schaltegger, U. 2015: The Bushveld Complex was emplaced and cooled in less than one million years - results of zirconology, and geotectonic implications. Earth and Planetary Science Letters 418: 103-114.

(Accepted 3 May 2016) 